\title{
Analisa Penentuan Saham Terbaik Menggunakan Metode Analytic Hierarchy Process (AHP)
}

\author{
Romindo \\ Prodi Manajemen Informatika, Politeknik Ganesha Medan, Medan, Indonesia \\ Email: romindo4@gmail.com \\ Email Penulis Korespondensi: romindo4@gmail.com
}

\begin{abstract}
Abstrak-Jumlah investor saham semakin meningkat dari dulu hingga saat ini. Begitu juga dengan jumlah perusahaan yang tercatat di Bursa Efek Indonesia (BEI). Yang dimana membuat investor bingung untuk memilih saham yang terbaik dari ratusan saham yang diperdagangkan di BEI.Metode yang digunakan untuk saham terbaik yaitu menggunakan metode Analytic Hierarchy Process (AHP). Investor akan memasukkan penilaian terhadap perbandingan antar kriteria dan antar alternatif tiap kriteria. Kriteria - kriteria yang digunakan untuk penentuan saham adalah $\mathrm{C} 1=\mathrm{PER}, \mathrm{C} 2=\mathrm{PBV}, \mathrm{C} 3=\mathrm{DER}$, $\mathrm{C} 4=\mathrm{ROE}$ dan $\mathrm{C} 5=$ ROA. Hasil penelitian yang dilakukan memberi kesimpulan bahwa alternatif A1 = CPIN merupakan peringkat pertama dengan Priority Vector0.6536, alternatif A2 = JFPA menjadi peringkat kedua dengan Priority Vector 0.2013 dan alternatif A3 = MAIN menjadi peringkat ketiga dengan Priority Vector 0.1452.
\end{abstract}

Kata Kunci: Metode Analytic Hierarchy Process; PenentuanSaham Terbaik; Sistem Pendukung Keputusan

\begin{abstract}
The number of stock investors has increased from the past to the present. Likewise, the number of companies listed on the Indonesia Stock Exchange (IDX). What makes investors confused about choosing the best stock from the hundreds of stocks that are regulated on the IDX. The method used for the best stock is the Analytic Hierarchy Process (AHP) method. Investors will enter criteria that take into account the specified criteria and criteria. The criteria used to determine stocks are $\mathrm{C} 1=\mathrm{PER}, \mathrm{C} 2=\mathrm{PBV}, \mathrm{C} 3=\mathrm{DER}, \mathrm{C} 4=\mathrm{ROE}$ and $\mathrm{C} 5=\mathrm{ROA}$. The results of research conducted in the second rank show that alternative A1 $=\mathrm{CPIN}$ is in the first rank with a Priority Vector of 0.6536 , alternative A2 $=$ JFPA is in the second rank with a Priority Vector of 0.2013 and alternative A3 = UTAMA is in the second rank. second rank. second rank. second rank. ranked third with a Priority Vector of 0.1452 .
\end{abstract}

Keywords: Analytical Hierarchy Process Method; Best Stock Selection; Decision Support System

\section{PENDAHULUAN}

Nabung saham mulai digemari pada zaman digital ini khususnya untuk investor. Selain kemudahan dan likuiditas yang relatif tinggi, Investasi pada saham biasanya memberikan keuntungan yang lebih tinggi dari tingkat inflasi. Saham itu sendiri merupakan suatu surat beharga yang menunjukkan bagian kepemilikan atas suatu perusahaan. Di Indonesia penjualan dan pembelian saham dilakukan di Bursa Efek Indonesia (BEI) melalui pialang (broker) yang dipilih sendiri dan diawasi oleh Otoritas Jasa Keuanagan (OJK) [1].

Memilih saham terbaik merupakan hal yang paling sulit dikarenakan perlunya pengalaman dan analisis yang mendalam[2]. Saham merupakan investasi yang beresiko tinggi karena fluktuasi harga dan likuidasi dari saham itu sendiri. Sehingga hal ini perlu dicermati oleh investor dalam penentuansaham terbaik. Pergerakan harga saham biasanya dipengaruhi oleh beberap faktor seperti laporan keuangan perusahaan, kinerja perusahaan, isu / berita dsb. Maksud dari saham terbaik itu sendiri adalah saham yang memiliki kriteria yang paling sesuai dengan harapan investor.

Dengan bantuan sistem pendukung keputusan (SPK) ini dapat memudahkan investor dalam memilihan saham yang terbaik. SPK adalah sistem informasi yang membantu suatu bisnis ataupun organisasi dalam pengambilan suatu keputusan. Dengan menggunakan sistem ini, Investor dapat mempercepat dan memudahkan analisis untuk menentukan altenatif terbaik atau saham terbaik [2]-[4].

Penelitian terhadap sistem pendukung keputusan sudah dilakukan oleh beberapa peneliti yaitu [5] yang menggunakan metode AHP untuk memprioritaskan perbaikian jalan dengan menggunakan multi-kriteria dalam perumusan alternatif. Pada penelitian tersebut menghasilkan peringkat dalam skala prioritas perbaikan jalan berdasarkan persepsi dari responden.[6] Menerapkan metode Fuzzy Technique for Order Preference by Similarity to Ideal Solution (FTOPSIS) padapenentuansaham terbaik berdasarkan analisis rasio keuangan. Metode menggunakan prinsip bahwa alternatif yang terpilih harus mempunyai jarak terdekat dari solusi ideal positif dan terjauh dari solusi ideal negatif untuk menentukan kedekatan relatif dari suatu alternatif dengan solusi optimal [7]-[9].

Analytical Hierarchy Process (AHP) merupakan metode untuk menyelesaikan suatu permasalahan yang memiliki struktur hierarki yang rumit dan membantu pengambilan suatu keputusan [10]. Metode ini digunakan untuk menentukan saham terbaik karena metode AHP dapat menganalisis permasalahan yang kompleks dengan kriteria seperti Price to Earnings Ratio (PER), Price to Book Value (PBV), Debt to Equity Ratio (DER), Return on Equity (ROE), Return on Assets (ROA).

Melihat dari permasalahan yang ditemukan pada penelitian sebelumnya, maka penulis melakukan penelitian dalam menentukan saham terbaik dan mengangkat judul "Analisa Penentuan Saham Terbaik 
MenggunakanMetode Analytic Hierarchy Process (AHP)". Dengan sistem yang akan dikembangkan diharapkan dapat membantu investor untuk memilih saham terbaik dengan metode AHP.

\section{METODOLOGI PENELITIAN}

\subsection{Analytic Hierarchy Process (AHP)}

Dikembangkan oleh seorang guru besar matermatika dari University of Pittsburgh pada tahun 1970 yaitu Prof. Thomas L. Saaty. Metode ini adalah suatu metode yang membantu SPK untuk menyelesaikan suatu keputusan yang memiliki kriteria yang banyak. Caranya yaitu dengan menggabungkan nilai perbandingan berpasangan pada setiap tingkat pada hierarki dengan lainnya. Setelah itu tetapkan bobot priortias pada setiap elemen [5], [11]-[13].

AHP merupakan suatu alat / metode yang menguraikan suatu masalah yang rumit pada struktur hierarki yang berisi alternatif, kriteria dan tujuan. Hierarki ini menggambarkan perkara yang rumit pada struktur yang banyak tingkatan dimana pada tingkatan pertama merupakan tujuan, selanjutnya kriteria atau subkriteria dan sampai pada tingkatan terakhir yaitu alternatif [14]-[17]. Menurut Saaty, metode AHP memiliki beberapa prinsip yaitu:

\section{a. Decompocition}

Yaitu membongkar masalah yang lengkap menjadi elemen - elemen yang tidak mungkin di bedah lagi sehingga menghasilkan beberapa tingkatan dari permasalahan itu.

b. Comparative judgement

Merupakan inti pada metode ini, dimana kita membuat penilaian kepentingan relatif antara dua komponen pada suatu tingkat tertentu yang berkaitan dengan tingkatan yang ada di atasnya. Penilaian ini ditampilkan dalam bentuk matrik (pairwise comparison) yang mempengaruhi nilai prioritas pada komponen - komponen. Biasanya untuk membuat skala prioritas dengan pertanyaan seperti apakah unsur A terhadap unsur B adalah sangat penting/penting/biasa/tidak penting/dst.

c. Synthesis of priority

Setiap matrik akan dihitung nilai eigen vector yang menghasilkan local priority. Untuk mendapatkan nilai global priority, maka local priority pada setiap tingkat akan disintesa menurut tingkatannya. Priority setting merupakan pengurutan elemen - elemen menurut kepentinan relatif dengan prosedur sintesa.

d. Logical consistency

Mempunyai dua maksud yaitu berdasarkan relevan dan keragamannya elemen - elemen dapat dikelompokkan menjadi elemen yang sejenis. Maksud lainnya adalah tingkat interaksi antara elemen berdasarkan kriteria tertentu. Sesudah permasalahan diuraikan, maka terdapat dua tahapan penilaian antara elemen yaitu perbandingan antara kriteria dan perbandingan antara alternatif untuk setiap criteria [5].

Tahapan Metode AHP

a. Menetapkan solusi dan permasalahan yang diinginkan.

b. Buatlah sistem hierarki yang dimulai dari tujuan hingga alternatif seprti gambar dibawah.

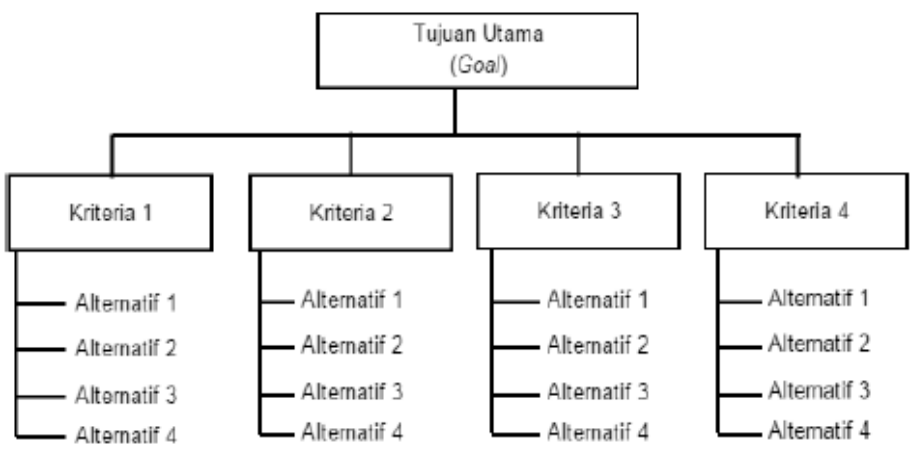

Gambar 1. Struktur Hieararki Model AHP[11]

c. Buatlah matrik perbandingan berpasangan terhadap tujuan dan kriteria yang setingkat di atasnya pada setiap elemen yang berada dibawahnya.

Tabel 1. Matrik Perbandigan Berpasangan Bobot Elemen

\begin{tabular}{ccccc}
\hline & Kriteria-1 & Kriteria-2 & $\ldots$ & Kriteria-j \\
\hline Kriteria-1 & $\mathrm{C}_{11}$ & $\mathrm{C}_{12}$ & $\ldots$ & $\mathrm{C}_{1 \mathrm{j}}$ \\
Kriteria-2 & $\mathrm{C}_{21}$ & $\mathrm{C}_{22}$ & $\ldots$ & $\mathrm{C}_{2 \mathrm{j}}$ \\
$\ldots$ & $\ldots$ & $\ldots$ & $\ldots$ & $\ldots$ \\
Kriteria-i & $\mathrm{C}_{\mathrm{i} 1}$ & $\mathrm{C}_{\mathrm{i} 2}$ & $\ldots$ & $\mathrm{C}_{\mathrm{ij}}$ \\
\hline
\end{tabular}




\section{JURNAL MEDIA INFORMATIKA BUDIDARMA}

Volume 5, Nomor 3, Juli 2021, Page 790-798

ISSN 2614-5278 (media cetak), ISSN 2548-8368 (media online)

Available Online at https://ejurnal.stmik-budidarma.ac.id/index.php/mib

DOI 10.30865/mib.v5i3.2978

\section{Sumber: [11]}

d. Tentukan penilaian pada perbadingan berpasangan dengan skala penilaian pada tabel dibawah. Dimana untuk mendapatkan jumlah penilai keseluruhan dengan rumus $n \times[(n-1) \div 2]$, dengan $n$ merupakan jumlah elemen yang dibandingkan.

Tabel 2. Skala Penilaian Perbandingan Berpasangan

\begin{tabular}{|c|c|c|}
\hline $\begin{array}{c}\text { Nilai } \\
\text { Kepentingan }\end{array}$ & Definisi & Penjelasan \\
\hline 1 & Equal importance & Kedua elemen memiliki kepentingan yang sama. \\
\hline 3 & Moderate more importance & $\begin{array}{l}\text { Satu elemen memiliki kepentingan sedikit lebih penting dari } \\
\text { lainnya. }\end{array}$ \\
\hline 5 & $\begin{array}{l}\text { Essential, strong more } \\
\text { importance }\end{array}$ & Satu elemen lebih penting dari elemen lainnya. \\
\hline 7 & Demonstrated importance & $\begin{array}{l}\text { Dimana suatu elemen sangat penting dibandingkan elemen } \\
\text { yang lain. }\end{array}$ \\
\hline 9 & $\begin{array}{l}\text { Absolutely more } \\
\text { importance }\end{array}$ & $\begin{array}{l}\text { Elemen dipastikan mutlak penting dari elemen lainnya dan } \\
\text { tidak bisa disangkal. }\end{array}$ \\
\hline $2,4,6,8$ & grey area & Jika adanya bimbangan diantara penilaian. \\
\hline
\end{tabular}

Sumber: [5]

e. Tentukan bobot pada setiap elemen dari tingkat paling bawah hingga paling atas dengan menghitung eigen vector pada setiap matrik perbandingan berpasangan.

Perhitungan eigen vector yaitu dengan membagikan nilai setiap elemen dengan jumlah nilai pada setiap kolom yang berkaitan untuk memperoleh normalisasi dalam matrik, Selanjutnya bagikan jumlahkan nilai pada setiap baris yang bersangkutan dengan jumlah elemen. Apabila matrik perbandingan berpasangan adalah A, maka bobot yang dibentuk:

$$
(A)\left(W^{T}\right)=(n)\left(W^{T}\right)
$$

dengan pendekatan:

1. Normalisasi matrik A pada setiap kolom j dengan persamaan:

$$
\sum_{i} a(i, j)=1
$$

2. Hitung nilai rata - rata pada setiap baris $\mathrm{i}$, dengan $w_{i}$ merupakan nilai bobot pada baris $i$ dan $n$ adalah jumlah elemen dengan persamaan:

$$
w_{i}=\frac{1}{n} \sum_{i} a(i, j)
$$

f. Mengecek konsistensi pada perhitungan

$A$ merupakan matrik perbandingan berpasangan. $W$ merupakan bobot, maka konsistensi dari bobot $W$ dapat dihitung dengan cara:

1. Hitung $(\mathrm{A})\left(\mathrm{w}^{\mathrm{T}}\right)$

$$
t=\frac{1}{n} \sum_{i=1}^{n}\left(\frac{\text { elemenke-ipada }(A)\left(W^{T}\right)}{\text { elemenke-ipada } W^{T}}\right)
$$

2. Hitung Consistency Index (CI):

$$
C I=\frac{t-n}{n-1}
$$

3. Tentukan nilai $\mathrm{RI}_{\mathrm{n}}$ dimana nilai RI sesuai dengan jumlah elemen yang dibandingkan

Tabel 2.Random Indeks

\begin{tabular}{cccccccc}
\hline $\mathrm{n}$ & 2 & 3 & 4 & 5 & 6 & 7 & $\ldots$ \\
\hline $\mathrm{RI}_{\mathrm{n}}$ & 0 & 0,58 & 0,90 & 1,12 & 1,24 & 1,32 & $\ldots$ \\
\hline
\end{tabular}

4. Hitunglah nilai Consistency Ratio (CR), jika nilai CR lebih besar dari 0,1 maka perhitungan dianggap tidak konsisten dan harus mengulangi dari tahap 4. Jika $\mathrm{CR}=0$ atau lebih kecil dari 0,1 maka perhitungan cukup konsisten. Perhitungan nilai CR dengan rumus [10]:

$$
C R=\frac{C I}{R I_{n}}
$$




\section{HASIL DAN PEMBAHASAN}

Perhitungan metode AHP secara manual yaitu dengan menghitung bobot prioritas kriteria dan alternatif [18]. Kriteria merupakan komponen utama untuk menenetukan hasil perhitungan. Sedangkan alternatif adalah komponen yang akan dibandingkan. Berikut merupakan perhitungan metode AHP secara manual:

a. Kriteria yang akan digunakan yaitu:
1. $\mathrm{C} 1=\mathrm{PER}$
2. $\mathrm{C} 2=\mathrm{PBV}$
3. $\mathrm{C} 3=\mathrm{DER}$
4. $\mathrm{C} 4=\mathrm{ROE}$
5. $\mathrm{C} 5=\mathrm{ROA}$

b. Alternatif yang akan digunakan yaitu:
1. $\mathrm{A} 1=\mathrm{CPIN}$
2. $\mathrm{A} 2=\mathrm{JFPA}$
3. $\mathrm{A} 3=\mathrm{MAIN}$

c. Masukkan nilai pada matrik perbandingan berpasangan pada kriteria seperti pada tabel dibawah dengan cara:

1. Memasukkan nilai 1 jika kriteria yang dibandingkan sama atau memiliki kepentingan yang sama.

2. Masukkan nilai antar 2 sampai 9 (sesuai dengan bobot kepentingan) pada tabel dengan membandingkan baris terhadap kolom. Sebaliknya jika kriteria yang dibandingkan sama namun berbeda posisinya maka nilainya yaitu 1/ (nilai bobot sebelumnya). Contohnya jika $\mathrm{C} 1$ terhadap $\mathrm{C} 2$ yaitu 5 , maka $\mathrm{C} 2$ terhadap $\mathrm{C} 1$ yaitu $1 / 5$.

Tabel 4. Matrik Perbandingan Berpasangan Kriteria

\begin{tabular}{cccccc}
\hline Kriteria & C1 & C2 & C3 & C4 & C5 \\
\hline C1 & 1 & 1 & $1 / 3=0.3333$ & $1 / 5=0.2$ & $1 / 2=0.5$ \\
C2 & 1 & 1 & $1 / 3=0.3333$ & $1 / 5=0.2$ & $1 / 2=0.5$ \\
C3 & 3 & 3 & 1 & $1 / 5=0.2$ & 3 \\
C4 & 5 & 5 & 5 & 1 & 3 \\
C5 & 2 & 2 & $1 / 3=0.3333$ & $1 / 3=0.3333$ & 1 \\
\hline
\end{tabular}

d. Jumlahkan nilai pada setiap kolom pada tabel 4 seperti dibawah ini:
$\mathrm{C} 1: 1+1+3+5+2$
$=12$
$\mathrm{C} 2: 1+1+3+5+2$
$=12$
C3: $0.3333+0.3333+1+5+0.3333$
$=7$
C4: $0.2+.02+0.2+1+0.3333$
$=1.9333$
C5: $0.5+0.5+3+3+1$
$=8$

e. Normalisasi setiap elemen pada tabel 5 dengan cara membagikan setiap elemen dengan jumlah nilai total pada setiap kolom (bagian 4) yaitu sebagai berikut:

Normalisasi kolom C1:

$$
\begin{aligned}
& C 1=\frac{1}{12}=0.0833 \\
& C 2=\frac{1}{12}=0.0833 \\
& C 3=\frac{3}{12}=0.25 \\
& C 4=\frac{5}{12}=0.4167 \\
& C 5=\frac{2}{12}=0.1667
\end{aligned}
$$

Normalisasi kolom C2:

$$
\begin{aligned}
& C 1=\frac{1}{12}=0.0833 \\
& C 2=\frac{1}{12}=0.0833 \\
& C 3=\frac{3}{12}=0.25 \\
& C 4=\frac{5}{12}=0.4167 \\
& C 5=\frac{2}{12}=0.1667
\end{aligned}
$$


JURNAL MEDIA INFORMATIKA BUDIDARMA

Volume 5, Nomor 3, Juli 2021, Page 790-798

ISSN 2614-5278 (media cetak), ISSN 2548-8368 (media online)

Available Online at https://ejurnal.stmik-budidarma.ac.id/index.php/mib

DOI 10.30865/mib.v5i3.2978

Tabel 5. Hasil Matrik Normalisasi Kriteria

\begin{tabular}{cccccc}
\hline Kriteria & C1 & C2 & C3 & C4 & C5 \\
\hline C1 & 0.0833 & 0.0833 & 0.0476 & 0.1034 & 0.0625 \\
C2 & 0.0833 & 0.0833 & 0.0476 & 0.1034 & 0.0625 \\
C3 & 0.25 & 0.25 & 0.1429 & 0.1034 & 0.375 \\
C4 & 0.4167 & 0.4167 & 0.7143 & 0.5172 & 0.375 \\
C5 & 0.1667 & 0.1667 & 0.0476 & 0.1724 & 0.125 \\
\hline
\end{tabular}

f. Setelah normalisasi, hitunglah priority vector dengan cara membagi jumlah semua elemen pada tiap baris dengan jumlah kriteria.

PV C1: $\frac{(0.0833+0.0833+0.0476+0.1034+0.0625)}{5}=0.0760$
PV C2: $\frac{(0.0833+0.0833+0.0476+0.1034+0.0625)}{5}=0.0760$
PV C3: $\frac{(0.25+0.25+0.1429+0.1034+0.375)}{5}=0.2243$
PV C4: $\frac{(0.4167+0.4167+0.7143+0.5172+0.375)}{5}=0.4880$
PV C5: $\frac{(0.1667+0.1667+0.0476+0.1724+0.125)}{5}=0.1357$

g. Dari hasil perhitungan priority vector, $\mathrm{C} 4$ merupakan bobot tertinggi dalam menentukan saham terbaik, selanjutnya $\mathrm{C} 3, \mathrm{C} 5, \mathrm{C} 1$ dan $\mathrm{C} 2$.

Tabel 6.Priority Vector Kriteria

\begin{tabular}{cccc}
\hline Kriteria & Priority Vector & Persentase & Peringkat \\
\hline C4 & 0.4880 & $48.8 \%$ & 1 \\
C3 & 0.2243 & $22.43 \%$ & 2 \\
C5 & 0.1357 & $13.57 \%$ & 3 \\
C1 & 0.0760 & $7.6 \%$ & 4 \\
C2 & 0.0760 & $7.6 \%$ & 5 \\
\hline
\end{tabular}

h. Setelah mendapatkan priority vector pada setiap kriteria, perlu dicek apakah bobot yang dihitung konsisten atau tidak. Dengan cara yaitu:

1. Hitung lamda maksimun dengan persamaan dibawah ini:

$$
\begin{aligned}
& \lambda \max =(A)\left(W^{T}\right) \\
& =\left[\begin{array}{ccccc}
1 & 1 & 0.3333 & 0.2 & 0.5 \\
1 & 1 & 0.3333 & 0.2 & 0.5 \\
3 & 3 & 1 & 0.2 & 3 \\
5 & 5 & 5 & 1 & 3 \\
2 & 2 & 0.3333 & 0.3333 & 1
\end{array}\right] *\left[\begin{array}{c}
0.076 \\
0.076 \\
0.2243 \\
0.4880 \\
0.1357
\end{array}\right]=5.4237
\end{aligned}
$$

2. Hitung consistency index $(\mathrm{CI})$, dimana $\mathrm{n}$ adalah jumlah kriteria.

$$
C I=\frac{\lambda \max -n}{n-1}=\frac{5.4237-5}{5-1}=0.1059
$$

3. Tetapkan nilai RI yang diambil dari tabel 2.3 dengan $n=5$, maka:RI $=1.12$

4. Hitung rasio konsistensi (CR) dengan persamaan:

$$
C R=\frac{C I}{R I}=\frac{0.1059}{1.12}=0.0946
$$

Karena nilai dari $\mathrm{CR}<0.1$, maka ketidak konsistenan masih diterima dan jika lebih besar dari 0.1 maka ulangi lagi dari langkah 3 .

i. Selanjutnya menghitungpriority vector dari alternatif pada setiap kriteria. Dengan langkah yang sama pada perhitungan priority vector pada kriteria yaitu:

1. Perbandingan antar alternatif pada kriteria $\mathrm{C} 1$

Tabel 7. Matrik Perbandingan Berpasangan Alternatif pada Kriteria C1

\begin{tabular}{cccc}
\hline & A1 & A2 & A3 \\
\hline A1 & 1 & $1 / 5=0.2$ & $1 / 2=0.5$ \\
A2 & 5 & 1 & 4 \\
A3 & 2 & $1 / 4=0.25$ & 1 \\
Jumlah & 8 & 1.45 & 5.5 \\
\hline
\end{tabular}


JURNAL MEDIA INFORMATIKA BUDIDARMA

Volume 5, Nomor 3, Juli 2021, Page 790-798

ISSN 2614-5278 (media cetak), ISSN 2548-8368 (media online)

Available Online at https://ejurnal.stmik-budidarma.ac.id/index.php/mib

DOI 10.30865/mib.v5i3.2978

Tabel 8. Hasil Matrik Normalisasi Alternatif pada Kriteria C1

\begin{tabular}{cccc}
\hline & A1 & A2 & A3 \\
\hline A1 & 0.125 & 0.1379 & 0.0909 \\
A2 & 0.625 & 0.6897 & 0.7273 \\
A3 & 0.25 & 0.1724 & 0.1818 \\
\hline
\end{tabular}

Tabel 9. Priority Vector Alternatif pada Kriteria C1

\begin{tabular}{cccc}
\hline Alternatif & Priority Vector & Persentase & Peringkat \\
\hline A1 & 0.1179 & $11.79 \%$ & 3 \\
A2 & 0.6806 & $68.06 \%$ & 1 \\
A3 & 0.2014 & $20.14 \%$ & 2 \\
\hline
\end{tabular}

$\lambda \max =\left[\begin{array}{ccc}1 & 0.2 & 0.5 \\ 5 & 1 & 4 \\ 2 & 0.25 & 1\end{array}\right] *\left[\begin{array}{l}0.1179 \\ 0.6806 \\ 0.2014\end{array}\right]=3.0383$

$C I=\frac{3.0383-3}{3-1}=0.0191$

$C R=\frac{0.0191}{0.58}=0.0330$

2. Perbandingan antar alternatif pada kriteria $\mathrm{C} 2$

Tabel 10. Matrik Perbandingan Berpasangan Alternatif pada Kriteria C2

\begin{tabular}{cccc}
\hline & A1 & A2 & A3 \\
\hline A1 & 1 & $1 / 5=0.2$ & $1 / 9=0.1111$ \\
A2 & 5 & 1 & $1 / 3=0.3333$ \\
A3 & 9 & 3 & 1 \\
Jumlah & 15 & 4.2 & 1.4444 \\
\hline
\end{tabular}

Tabel 11. Hasil Matrik Normalisasi Alternatif pada Kriteria C2

\begin{tabular}{cccc}
\hline & A1 & A2 & A3 \\
\hline A1 & 0.0667 & 0.0476 & 0.0769 \\
A2 & 0.3333 & 0.2381 & 0.2308 \\
A3 & 0.6 & 0.7143 & 0.6923 \\
\hline
\end{tabular}

Tabel 12. Priority Vector Alternatif pada Kriteria C2

\begin{tabular}{cccc}
\hline Alternatif & Priority Vector & Persentase & Peringkat \\
\hline A1 & 0.0637 & $6.37 \%$ & 3 \\
A2 & 0.2674 & $26.74 \%$ & 2 \\
A3 & 0.6689 & $66.86 \%$ & 1 \\
\hline
\end{tabular}

$\lambda \max =\left[\begin{array}{ccc}1 & 0.2 & 0.1111 \\ 5 & 1 & 0.3333 \\ 9 & 3 & 1\end{array}\right] *\left[\begin{array}{l}0.0637 \\ 0.2674 \\ 0.6689\end{array}\right]=3.0453$

$C I=\frac{3.0453-3}{3-1}=0.0226$

$C R=\frac{0.0226}{0.58}=0.0390$

3. Perbandingan antar alternatif pada kriteria $\mathrm{C} 3$

Tabel 13. Matrik Perbandingan Berpasangan Alternatif pada Kriteria C3

\begin{tabular}{cccc}
\hline & A1 & A2 & A3 \\
\hline A1 & 1 & 9 & 8 \\
A2 & $1 / 9=0.1111$ & 1 & $1 / 2=0.5$ \\
A3 & $1 / 8=0.125$ & 2 & 1 \\
Jumlah & 1.2361 & 12 & 9.5 \\
\hline
\end{tabular}


JURNAL MEDIA INFORMATIKA BUDIDARMA

Volume 5, Nomor 3, Juli 2021, Page 790-798

ISSN 2614-5278 (media cetak), ISSN 2548-8368 (media online)

Available Online at https://ejurnal.stmik-budidarma.ac.id/index.php/mib

DOI 10.30865/mib.v5i3.2978

Tabel 14. Hasil Matrik Normalisasi Alternatif pada Kriteria C3

\begin{tabular}{cccc}
\hline & A1 & A2 & A3 \\
\hline A1 & 0.8090 & 0.75 & 0.8421 \\
A2 & 0.8090 & 0.0833 & 0.0526 \\
A3 & 0.1011 & 0.1667 & 0.1053 \\
\hline
\end{tabular}

Tabel 15.Priority Vector Alternatif pada Kriteria C3

\begin{tabular}{cccc}
\hline Alternatif & Priority Vector & Persentase & Peringkat \\
\hline A1 & 0.8004 & $80.04 \%$ & 1 \\
A2 & 0.0753 & $7.53 \%$ & 3 \\
A3 & 0.1244 & $12.44 \%$ & 2 \\
\hline
\end{tabular}

$$
\begin{aligned}
& \lambda \max =\left[\begin{array}{ccc}
1 & 9 & 8 \\
0.1111 & 1 & 0.5 \\
0.125 & 2 & 1
\end{array}\right] *\left[\begin{array}{l}
0.8004 \\
0.0753 \\
0.1244
\end{array}\right]=3.0741 \\
& C I=\frac{3.0741-3}{3-1}=0.037 \\
& C R=\frac{0.037}{0.58}=0.0639
\end{aligned}
$$

4. Perbandingan antar alternatif pada kriteria $\mathrm{C} 4$

Tabel 16. Matrik Perbandingan Berpasangan Alternatif pada Kriteria C4

\begin{tabular}{cccc}
\hline & A1 & A2 & A3 \\
\hline A1 & 1 & 5 & 7 \\
A2 & $1 / 5=0.2$ & 1 & 3 \\
A3 & $1 / 7=0.1429$ & $1 / 3=0.3333$ & 1 \\
Jumlah & 1.3429 & 6.3333 & 11 \\
\hline
\end{tabular}

Tabel 17. Hasil Matrik Normalisasi Alternatif pada Kriteria C4

\begin{tabular}{cccc}
\hline & A1 & A2 & A3 \\
\hline A1 & 0.7447 & 0.7895 & 0.6364 \\
A2 & 0.1489 & 0.1579 & 0.2727 \\
A3 & 0.1064 & 0.0526 & 0.0909 \\
\hline
\end{tabular}

Tabel 18. Priority Vector Alternatif pada Kriteria C4

\begin{tabular}{cccc}
\hline Alternatif & Priority Vector & Persentase & Peringkat \\
\hline A1 & 0.7235 & $72.35 \%$ & 1 \\
A2 & 0.1932 & $19.32 \%$ & 2 \\
A3 & 0.0833 & $8.33 \%$ & 3 \\
\hline
\end{tabular}

$$
\begin{aligned}
& \lambda \max =\left[\begin{array}{ccc}
1 & 9 & 8 \\
0.1111 & 1 & 0.5 \\
0.125 & 2 & 1
\end{array}\right] *\left[\begin{array}{l}
0.7235 \\
0.1932 \\
0.0833
\end{array}\right]=3.1115 \\
& C I=\frac{3.1115-3}{3-1}=0.0557 \\
& C R=\frac{0.0557}{0.58}=0.0961
\end{aligned}
$$

5. Perbandingan antar alternatif pada kriteria C5

Tabel 19. Matrik Perbandingan Berpasangan Alternatif pada Kriteria C5

\begin{tabular}{cccc}
\hline & A1 & A2 & A3 \\
\hline A1 & 1 & 7 & 9 \\
A2 & $1 / 7=0.1429$ & 1 & 2 \\
A3 & $1 / 9=0.1111$ & $1 / 2=0.5$ & 1 \\
Jumlah & 1.2540 & 8.5 & 12 \\
\hline
\end{tabular}


ISSN 2614-5278 (media cetak), ISSN 2548-8368 (media online)

Available Online at https://ejurnal.stmik-budidarma.ac.id/index.php/mib DOI 10.30865/mib.v5i3.2978

Tabel 20. Hasil Matrik Normalisasi Alternatif pada Kriteria C5

\begin{tabular}{cccc}
\hline & A1 & A2 & A3 \\
\hline A1 & 0.7975 & 0.8235 & 0.7500 \\
A2 & 0.1139 & 0.1176 & 0.1667 \\
A3 & 0.0886 & 0.0588 & 0.0833 \\
\hline
\end{tabular}

Tabel 21. Priority Vector Alternatif pada Kriteria C5

\begin{tabular}{cccc}
\hline Alternatif & Priority Vector & Persentase & Peringkat \\
\hline A1 & 0.7903 & $79.03 \%$ & 1 \\
A2 & 0.1327 & $13.27 \%$ & 2 \\
A3 & 0.0769 & $7.69 \%$ & 3 \\
\hline
\end{tabular}

$$
\begin{aligned}
& \lambda \max =\left[\begin{array}{ccc}
1 & 7 & 9 \\
0.1429 & 1 & 2 \\
0.1111 & 0.5 & 1
\end{array}\right] *\left[\begin{array}{l}
0.7903 \\
0.1327 \\
0.0769
\end{array}\right]=3.0425 \\
& C I=\frac{3.0425-3}{3-1}=0.0212 \\
& C R=\frac{0.0212}{0.58}=0.0366
\end{aligned}
$$

j. Setelah mendapatkan priority vector setiap kriteria dan alternatif tiap kriteria, Hitunglah priority vector alternatif untuk mendapatkan alternatif yang terbaik dengan cara mengkalikan PV alternatif tiap kriteria dengan PV kriteria, yaitu:

$\left[\begin{array}{lllll}0.1179 & 0.0637 & 0.8004 & 0.7235 & 0.7903 \\ 0.6806 & 0.2674 & 0.0753 & 0.1932 & 0.1327 \\ 0.2014 & 0.6689 & 0.1244 & 0.0833 & 0.0769\end{array}\right] *\left[\begin{array}{l}0.0760 \\ 0.0760 \\ 0.2243 \\ 0.4880 \\ 0.1357\end{array}\right]=\left[\begin{array}{l}0.6536 \\ 0.2013 \\ 0.1452\end{array}\right]$

Tabel 22. Priority Vector Alternatif

\begin{tabular}{cccc}
\hline Alternatif & Priority Vector & Persentase & Peringkat \\
\hline A1 & 0.6536 & $65.36 \%$ & 1 \\
A2 & 0.2013 & $20.13 \%$ & 2 \\
A3 & 0.1452 & $14.52 \%$ & 3 \\
\hline
\end{tabular}

Dari hasil perhitungan diatas, A1 memiliki nilai yang tertinggi. Sehingga A1 (CPIN) merupakan saham terbaik dari ketiga alternatif yang dibandingkan.

\section{KESIMPULAN}

Analytic Hierarchy Process (AHP) merupakan suatu alat / metode yang menguraikan suatu masalah yang rumit pada struktur hierarki yang berisi alternatif, kriteria dan tujuan.Dengan diterapkannya metode Analytic Hierarchy Process pada penentuan saham terbaik, makadapat membantu dalam memilih saham berdasarkan analisis fundamental dengan lebih mudah. Hasil perhitungan dengan menggunakan metode Analytic Hierarchy Processyang memiliki 5 kriteria, yaitu: C1, C2, C3, C4 dan C5dapat disimpulkan bahwa alternatif A1 merupakan peringkat pertama dengan Priority Vector0.6536, alternatif A2 menjadi peringkat kedua dengan Priority Vector 0.2013 dan alternatif A3 menjadi peringkat ketiga dengan Priority Vector 0.1452 .

\section{REFERENCES}

[1] D. P. E. Brilliand, R. R. Hidayat, and A. Darmawan, "Analisis Fundamental dalam Penilaian Harga Saham dengan Menggunakan Metode Dividen Discounted Model dan Price Earning Ratio (Studi Pada Perusahaan Multinasional Sub Sektor Semen yang terdaftar di Bursa Efek Indonesia Periode 2013-2015),” J. Adm. Bisnis, vol. 37, 2016.

[2] T. Sutojo, E. Mulyanto, and V. Suhartono, Kecerdasan Buatan. Yogyakarta: Andi, 2011.

[3] N. Septian, N. Fhira, and A. Adiwijaya, "Rainfall Prediction in Kemayoran Jakarta Using Hybrid Genetic Algorithm (GA) and Partially Connected Feedforward Neural Network," in Second International Conference on Information and Communication Technology (ICoICT), 2014.

[4] A. Adiwijaya, M. N. Aulia, M. S. Mubarok, U. N. W, and F. Nhita, "A Comparative Study of MFCC-KNN and LPCKNN for Hijaiyyah Letters Pronounciation Classification System," in International Conference on Information and Communication Technology (ICoICT), 2017.

[5] D. Nababan, "PRIORITAS PERBAIKAN JALAN DI KOTA MEDAN DENGAN MENGGUNAKAN METODE ANALITYCAL HIERARCHY PROCESS (AHP),” Mandiri Bina Prestasi, vol. 3, no. 2, pp. 14-19, 2014.

[6] A. B. Paksi, "Penerapan F-TOPSIS Dalam Analisis Fundamental Berdasarkan Rasio Keuangan Untuk Menunjang 
Keputusan Berinvestasi Saham,” in Seminar Nasional Teknologi Informasi dan Multimedia, 2016, pp. 127-132.

[7] R. Romindo, "Implementasi Metode ANP Terhadap Sistem Pendukung Keputusan Memilih Toko Daring Terbaik," J. MEDIA Inform. BUDIDARMA, vol. 3, no. 4, pp. 254-260, 2019.

[8] Indarto, Abdiansah, and Adriana, Penalaran Komputer Berbasis Kasus (Case Based Reasoning). Yogyakarta: Ardana Media, 2008.

[9] S. W. F. Akmal, "SISTEM PPAKAR UNTUK MENDIAGNOSA PENYAKIT LAMBUNG DENGAN IMPLEMENTASI METODE CBR (CASE BASED REASONING) BERBASIS WEB,” J. Sarj. Tek. Inform., vol. 2, no. $1,2014$.

[10] A. E. Muntafa and H. Mubarok, "Penerapan Metode Analytical Hierarchy Process Dalam Sistem Pendukung Keputusan Penentuan Mahasiswa Berprestasi," J. Siliwangi, vol. 3, no. 2, 2017.

[11] K. Kusrini, Sistem Pakar Teori dan Aplikasi, 1st ed. Yogyakarta: ANDI, 2006.

[12] J. S. D. Raharjo, "Model Artificial Neural Network berbasis Particle Swarm Optimization untuk Prediksi Laju Inflasi," J. Sist. Komput., vol. 3, no. 1, pp. 10-21, 2013.

[13] T. Limbong et al., Sistem Pendukung Keputusan: Metode \& Implementasi. Medan: Yayasan Kita Menulis, 2020.

[14] M. Astradant, I. M. A. Wirawan, and I. K. R. Arthana, "Pengembangan Sistem Penunjang Keputusan Pemilihan Tempat Kuliner Dengan Menggunakan Metode AHP Dan SAW Studi Kasus : Kecamatan Buleleng," Kumpul. Artik. Mhs. Pendidik. Tek. Inform., vol. 5, no. 2, 2016.

[15] S. R. Abdul Rojak and A. Rifai, "Penerapan Metode Analytical Hierarchy Process dalam Memilih Bahan Bakar Minyak untuk Kendaraan Roda Dua," J. Kaji. Ilm., vol. 18, no. 1, pp. 1-8, 2018.

[16] K. Safitri, F. T. Waruwu, and M. Mesran, "SISTEM PENDUKUNG KEPUTUSAN PEMILIHAN KARYAWAN BERPRESTASI DENGAN MENGGUNAKAN METODE ANALYTICAL HIEARARCHY PROCESS (Studi Kasus : PT.Capella Dinamik Nusantara Takengon)," MEDIA Inform. BUDIDARMA, vol. 1, no. 1, Feb. 2017.

[17] Masitha, D. Hartama, and A. Wanto, "Analisa Metode (AHP) Pada Pembelian Sepatu Sekolah Berdasarkan Konsumen," in Seminar Nasional Sains dan Teknologi Informasi (SENSASI), 2018.

[18] R. Romindo, "Implementasi Metode SAW Terhadap Sistem Pendukung Keputusan Memilih Dosen Terbaik Pada Politeknik Ganesha," Ris. dan E-Jurnal Manaj. Inform. Komput., vol. 5, no. 1, pp. 91-95, 2020. 